\title{
Analisis Penerapan Akuntansi Sewa Guna Usaha (PSAK 30)
}

\section{Studi Kasus Pada PT. BFI Finance Indoneisa Tbk.}

\author{
Farid Hardiansyah Haris dan Rachmawaty Rachman \\ Program Studi Akuntansi, Institut Bisnis dan Informatika Kesatuan \\ EMail: farid.haris@gmail.com
}

Submitted: JANUARI 2020

Accepted: MARET 2021

\section{ABSTRACT}

This study aims to determine the system of finacing, recording, and presentation of lease accounting contracts applied by the company thather it has been in accordance with the statement of financial accounting standards 30. The results of the research show that in its operational activities the company uses the method of financing lease, because in the lease contract the company transfers subtantially all the risk and rewards assaciated with the ownership og the asset. In the contract the company recognizes assets in the from rental receivables in the amount equal to the net rental investment. The receivable from rental receivable treated as principal payment which will be presented in the statement of financial position and the finance lease income to be presented in the statement of financial position and the financial lease income to be presented in the statement of income. In general, the accounting standart 30 which has been described in the noted to the financial statement of the company. With the provisions of accounting fo leases (PSAK 73) that have been retified by DSAK-IAI, in 2017 Effective as of 1 januari 2020, the company should consider the provisions in the application of the rental accounting policy in the subsequent period.

Keywords : Finance Lease, Statement of Financial Accounting Standart 30

\begin{abstract}
ABSTRAK
Penelitian ini bertujuan untuk mengetahui sistem pembiayaan, pencatatan, dan penyajian kontrak akuntansi sewa yang diterapkan oleh perusahaan serta kesesuaiannya dengan Pernyataan Standar Akuntansi Keuangan No.30. Hasil penelitian menunjukan bahwa kegiatan operasionalnya perusahaan menggunakan metode sewa pembiayaan (financial lease), karena dalam kontrak sewa perusahaan menyatakanadanya pengalihan secara subtansial seluruh resiko dan manfaat yang terkait dengan kepemilikan aset. Dalam kontrak tersebut perusahaan mengakui aset berupa piutang sewa pembiayaan sebesar jumlah yang sama dengan investasi sewa neto. Penerimaan piutang sewa diperlakukan sebagai pembayaran pokok yang disajikan ke dalam laporan laba rugi. Secara garis besar, akuntansi transaksi sewa perusahaan telah sesuai dengan PSAK 30 yang penjelasannya telah dituangkan dalam catatan atas laporan keuangan perusahaan. Dengan adanya ketentuan akuntansi sewa (PSAK 73) yang telah disahkan oleh DSAK - IAI pada tahun 2017 yang berlaku efektif per 1 januari 2020, maka perusahaan perulu memperhatikan ketentuan tersebut dalam penerapan kebijakan akuntansi sewa pada periode berikutnya.
\end{abstract}

Kata Kunci : Akuntansi Sewa, PSAK 30

\section{PENDAHULUAN}

Ada berbagai macam lembaga keuangan seperti Perbankan, lembaga keuangan bukan bank, lembaga pembiayaan. Lembaga pembiayaan tergolong lembaga yang relatif baru. Lembaga pembiayaan pada dasarnya adalah lembaga/badan usaha yang memberikan atau melakukan kegiatan pemberian dana atau barang modal. Dalam hal

\section{JIAKES}

$$
\begin{array}{r}
\text { Jurnal Ilmiah Akuntansi } \\
\text { Kesatuan } \\
\text { Vol. } 9 \text { No. 1, 2021 } \\
\text { pg. 109-120 } \\
\text { IBI Kesatuan } \\
\text { ISSN 2337 - 7852 } \\
\text { E-ISSN } 2721-3048
\end{array}
$$


Implementation of

Lease Accounting

in Indonesia

$\underline{110}$ ini tentunya lembaga pembiayaan memberikan pembiayaan bagi konsumen untuk melakukan pembayaran dengan menggunakan angsuran sesuai yang telah disepakati.

Keinginan manusia serta kebutuhan manusia dalam biaya hidup serta modal kadang memaksa konsumen untuk melakukan kegiatan pembiayaan. Contohnya adalah ketika seseorang konsumen ingin menambah modal usaha dia, biaya menjadi faktor penghalang untuk membesarkan usaha dia, namun jiga dia memiliki unit motor dan ada surat BPKB maka dia bisa melakukan kegiatan pembiayaan untuk mendapatkan modal dana dari perusahaan pembiayaan dan melakukan pembayaran secara cicilan dengan tenor yang telah disepakati. Menurut kasmir $(2016,241)$ kegiatan leasing secara resmi diperbolehkan beroperasi di Indonesia setelah keluar surat keputusan bersama antara Menteri Keuangan, Menteri Perindustrian dan Menteri Perdagangan Nomor Kep122/MK/2/1974, No. 32/M/SK/2/1974, dan No. 30/Kpb/I/74 tanggal 7 Febuari 1974 tentang perizinan usaha Leasing di Indonesia. Wewenang untuk memberikan usaha leasing di keluarkan oleh Menteri Keuangan berdasarkan Surat Keputusan Nomor 649/MK/IV/5/1974 tanggal 6 Mei 1974 yang mengatur mengenai ketentuan tata cara perizinan dan kegiatan usaha leasing di Indonesia.

Perkembangan selanjutnya adalah dengan dikeluarkanya kebijakan deregulasi 20 Desember 1988 (Pakdes 20 1998) yang isinya mengatur tentang usaha leasing di Indonesia dan dengan keluarnya kebijakan ini, maka ketentuan mengenai usaha leasing sebelumnya dinyatakan tidak berlaku lagi. Kemudia dalam peraturan Menteri Keuangan Nomor 84/PMK.012/2006 Keputusan Presiden Nomor 61 tahun 1988 dan Keputusan Menteri Keuangan Nomor 1251/KMK.013/1998 tanggal 20 Desember 1988 diperkenalkan adanya istilah pembiayaan, yaitu kegiatan pembiayaan dalam bentuk dana atau barang modal dengan tidak menarik dana secara langsung dari masyarakat luas. Kegiatan utama perusahaan leasing adalah bergerak dibidang pembiayaan untuk keperluan barang-barang modal yang diinginkan oleh nasabah. Pembiayaan di sini maksudnya jika seorang nasabah membutuhkan barang-barang modal seperti kendaraan baik itu motor atau mobil dengan disewa atau dibeli secara kredit dapat diperoleh di perusahaan leasing.

Pihak leasing dapat membiayai keinginan nasabah sesuai dengan perjanjian yang telah disepakati kedua belah pihak. Sehingga dengan adanya perusahaan leasing dapat membantu masyarakat dalam penyediaan modal, kepada perusahaan/perorangan yang membutuhkan agar dapat mengembangkan usahanya tanpa harus membayar dengan tunai, tetapi dapat diangsur dalam jumlah tertentu dan dalam jangka waktu pengembalian antara 6 (enam) bulan hingga 2 (dua) tahun atau lebih sesuai yang mereka kehendaki itu lebih meringankan bagi masyarakat yang ingin memiliki sebuah kendaraan bermotor. Dengan perkembangan leasing tersebut maka dibutuhkannya peranan akuntansi dalam suatu perusahaan sehingga timbul kebutuhan untuk menyediakan standar akuntansi keuangan yang dapat dijadikan sebagai pedoman dan penuntun praktik akuntansi untuk mencatat dan melaporkan transaksi leasing dalam laporan keuangan dan menghasilkan suatu laporan keuangan yang wajar serta informasi yang berguna bagi para pemakai laporan keuangan.

Hal ini dikarenakan akuntansi memberikan informasi keuangan yang sangat dibutuhkan oleh berbagai pihak, baik pihak internal maupun ekternal dalam proses pengambilan keputusan. Oleh karena itu, informasi berupa laporan keuangan suatu perusahaan merupakan interprestasi kondisi keuangan selama periode tertentu, sehingga fungsi laporan keuangan sangat memberikan peran penting dalam pengambilan keputusan, baik itu ditingkat manajemen maupun ditingkat shareholder atau investor terutama yang tidak terlibat langsung dalam operasi perusahaan. Oleh karena itu, yang mengatur standar akuntansi leasing diatur oleh PSAK 30 yang mengatur standar akuntansi dengan ruang lingkup dan karakteristik dalam laporan keuangan perusahaan yang harus mengacu pada pedoman standar akuntansi keuangan tersebut.

Laporan keuangan perusahaan adalah sebuah hasil dari catatan historis akuntansi mengenai transaksi yang dilakukan perusahaan dan mencerminkan bagaimana 
perushaan berjalan selama satu tahun periode kebelakang, memperlihatkan posisi financial perusahaan, dan rugi labanya perusahaan tersebut. Laporan keuangan perusahaan perlu dibuat secara relevan dan reliabel agar dapat menggambarkan keadaan perusahaan yang sebenarnya.

Melihat semakin berkembangnya kegiatan sewa guna usaha, maka dirasakan adanya kebutuhan untuk menyediakan suatu standar akuntansi keuangan yang dapat dijadikan sebagai pedoman untuk mencatat dan melaporkan transaksi sewa guna usaha dalam laporan keuangan, sehingga akan dihasilkan suatu laporan keuangan yang wajar dan informasi yang berguna bagi para pemakai laporan keuangan. Kegiatan sewa menyewa ini sangat bervariasi menurut kontraknya, variabel-variabel itu misalnya lama masa persewaan, persyaratan pembayaran dan pembelian, ayat-ayat mengenai pembatalan dan sanksi-sanksi, jaminan oleh penyewa mengenai nilai sisa, jumlah dan waktu pembayaran sewa, tingkat bunga yang terkandung dalam perjanjian sewa menyewa, dan pembayaran biaya-biaya tertentu seperti pemeliharan, asuransi, dan pajak. Hal-hal tersebut harus dipertimbangkan dalam menentukan perlakuan akuntansi yang tepat dalam sewa guna usaha.

Pada umumnya perusahaan salah dalam mengklasifikasikan apakah transaksi tersebut termasuk dalam financial lease atau operating lease. Karena untuk menentukan itu merupakan financial lease atau operating lease kita harus melihat dari jenis transaksinya jika transaksi tersebut mengalihkan kepemilikan aset kepada lesee pada akhir masa sewa itu berarti transaksi tersebut adalah financial lease dan jika tidak maka itu adalah transaksi operating lease. Dimana perusahaan salah menentukan jenis operasi, yang dimana jika menggunakan metode financial lease maka dalam pengakuan awal aset yang di akui berupa piutang sewa pembiayaan di laporan posisi keuangan sebesar jumlah yang sama dengan investasi sewa neto tersebut, sedangkan dalam operating lease lessor menyajikan aset untuk sewa operasi di laporan posisi keuangan sesuai sifat aset tersebut.

Ditinjau dari segi kewajiban, metode capital lease dapat memperbesar kewajiban yang ada di neraca. Hal ini dikarenakan metode capital lease menghendaki aktiva yang disewa guna usaha dicatat disisi debet sebagai aktiva sewa guna usaha dan kewajiban sewa guna usaha dicatat disisi kredit. Dengan sendirinya perhitungan risiko keuangan yang berhubungan dengan kewajiban akan tidak sesuai lagi jika dibandingkan dengan metode operating lease. Terkadang perusahaan juga salah dalam menentukan metode yang harusnya di gunakan dalam financial lease dan operating lease yang seharusnya financial lease menggunakan metode anuitas bukan dengan metode garis lurus, jika menggunakan metode garis lurus pada saat masa perjanjian leasing pembayaran uang muka sebagai simpanan jaminan, perusahaan mencatat pada kelompok aset lancar, sehingga di laporan posisi keuangan jumlah aset lancar lebih besar dari yang sebenarnya. Dengan salahnya jenis transaksi dan metode yang digunakan akan mempengaruhi penyajian laporan keuangan dan melenceng dari standar akuntansi yang sesuai dengan PSAK No. 30 yang ada.

Pada kasus penelitian yang dilakukan oleh Putri Rosita (2018) tentang "PENERAPAN PSAK NO.30 TENTANG AKUNTANSI SEWA ASET TETAP PADA PT. RACHMAT KELANTAN SAKTI DI PALEMBANG" menyatakan bahwa sewa yang dilakukan pada PT Rachmat Kelantan Sakti adalah sewa operasi, masalah yang ada pada PT. Rachmat Kelantan Sakti masih menggabungkan aset tetap perusahaan dengan aset tetap yang disewakan dalam satu nama akun, yaitu aset tetap. Seharusnya pada PSAK No. 30 itu harusnya di pisah dan juga Pada saat penelitian ini dilakukan, perusahaan pada tahun 2015-2016 belum melakukan penghitungan penyusutan aset tetap yang disewakan karena perusahaan hanya mencatat kas masuk, yaitu pendapatan sewa, dan kas keluar, yaitu beban pembelian spare part dan beban lain-lain. Menurut PSAK No. 30, perhitungan penyusutan aset tetap yang disewakan dihitung menggunakan metode garis lurus. Menurut Standar Akuntansi Keuangan (SAK), barang modal yang disewakan di laporkan berdasarkan harga perolehan setelah dikurangi akumulasi penyusutan. Dari hasil penelitian ini juga bisa di ambil bahwa
Implementation of

Lease Accounting in Indonesia

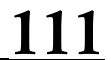


Implementation of

Lease Accounting

in Indonesia

112 perusahaan tersebut belum sesuai dengan PSAK No. 30 di karenakan pada perusahaan tersebut tidak melakukan perhitungan penyusutan dari aset tetap yang di sewakan. Hal tersebut terjadi karena pihak manajemen tidak mengetahui metode yang harus digunakan dalam perhiungan aset tetap yang sesuai dengan PSAK No. 30 terkait aset pada pelaporan keuangan sehingga perusahaan belum menghitung biaya penyusutan dari aset tetap yang disewakan tersebut. Lalu dalam hal pencatatan dan pengungkapan dalam pada perusahaan tidak di pisahkannya aset tetap dan aset tetap yang disewakan tentu saja berdampak pada penyusutan aset tetap dan penyusutan aset tetap yang di sewakan tidak terpisah juga.

Oleh sebab itu, metode pembiayaan dengan capital lease tidak dapat disamakan dengan perjanjian sewa menyewa biasa seperti halnya pada operating lease, sehingga perlakuan akuntansi untuk transaksi sewa guna usaha perlu diterapkan secara konsisten sesuai dengan PSAK No.30 dalam rangka penyusunan laporan keuangan perusahaan. Untuk itu guna menjawab berbagai pertentangan dan menjelaskan praktek sewa guna usaha perlu pengkajian dari sisi konsep-konsep akuntansi yang mendasar, sehingga dapat ditentukan perlakuan setiap transaksi sewa guna usaha secara tepat, dapat dimengerti, dapat diperbandingkan dan sesuai dengan tujuan laporan keuangan. Laporan keuangan yang merupakan hasil akhir dari proses akuntansi tersebut harus dapat memberikan suatu rangkaian historis dari sumber-sumber ekonomi, kewajibankewajiban perusahaan serta kegiatan-kegiatan yang mengakibatkan perubahanperubahan terhadap sumber-sumber ekonomi dan kewajiban-kewajiban tersebut. Sehingga informasi yang dihasilkan dari laporan keuangan tersebut akan dapat dijadikan sebagai dasar pengambilan keputusan perusahaan untuk periode akuntansi berikutnya.Data keuangan dalam laporan keuangan akan lebih berarti apabila analisis lebih lanjut sehingga dapat memperoleh informasi yang dapat mendukung keputusan yang diambil. Dengan deimikian analisis akuntansi leasing berdasarkan PSAK No. 30 merupakan analisis yang dilakukan berbagai macam informasi mengenai perlakuan dan pelaporan transaksi akuntansi leasing dalam suatu laporan keuangan perusahaan.

Namun masih banyak perusahaan perusahaan pembiayaan yang masih yang bekum menerapkan PSAK 30 secara benar contohnya sepeti analisis yang dilakukan oleh Meiki sumual dan Dhullo afandi Dengan judul" ANALISIS PERLAKUAN AKUNTANSI LEASING DAN PELAPORANNYA PADA PT. ASTRA SEDAYA FINANCE DI MANADO" Berdasarkan hasil pembahasan dalam penelitian ini, adapun saran yang dapat penulis kemukakan sebagai berikut: 1. P.T. Astra Sedaya Finance sebaiknya melakukan pemisahan pencatatan penyusutan aktiva tetap dengan aktiva yang disewagunakan. Sesuai dengan PSAK 30. 2. PT. Astra Sedaya Finance sebaiknya selalu mengikuti perkembangan peraturan pelaporan yang terkait dengan transaksi leasing, sehingga tidak menimbulkan banyak perbedaan antara perlakuan akuntansi dengan menggunakan metode pencatatan perusahaan. Dalam penelitian ini perusahaan belum menerapkan secara konsisten penerapan PSAK 30 secara penuh.

Tujuan penelitian ini adalah untuk:

1. Untuk mengetahui sistem pembiayaan sewa guna usaha pada PT. BFI Finance Indonesia Tbk.

2. Untuk mengetahui perlakuan akuntansi sewa pada PT. BFI Finance Indonesia Tbk.

3. Untuk Mengetahui penyajian laporan keuangan akuntansi sewa pada PT. BFI Finance Indonesia Tbk.

\section{METODE PENELITIAN}

Penelitian ini dilaksanakan di BFI Finance Jalan Raya Tajur No. 118, Tajur, Bogor Timur, Pakuan, Bogor Sel., Kota Bogor, Jawa Barat 16141. Waktu penelitian dari bulan Juli sampai dengan Desember 2020. Sumber data yang digunakan dalam penelitian ini adalah data sekunder. Data sekunder yang dibutuhkan merupakan data yang diperoleh dari bursa efek indonesia (BEI) berupa laporan keuangan periode 3 tahun terakhir. Metode analisis deskriptif komparatif dalam penelitian ini menggunakan identifikasi 
masalah secara terperinci dan sistematis dengan penekanan pada perbandingan hasil riset lapangan dengan teori terkini dan relevan yang diperoleh dari hasil riset kepustakaan. Dimana peneliti akan melakukan perbandingan pada laporan keuangan PT. BFI Finance Indonesia Tbk. terkait dengan judul penelitian penelitianmaka analisis yang dilakukan adalah membandingkan apakah PT. BFI Finance Indonesia Tbk. Telah menerapkan akuntansi leasing pada laporan keuangannya sesuai dengan PSAK No.30 yang berlaku di Indonesia sebagai Standar Akuntansi Leasing.

\section{HASIL DAN PEMBAHASAN}

Sistem pembiayaan sewa guna usaha pada PT. BFI Finance indonesia Tbk.,

Pihak pihak yang terkait dalam pembiayaan yaitu : Konsumen/calon nasabah, Perusahaan leasing yang menyediakan dana dan Dealer. Dimana pelaksanaannya sebagai berikut :

a. Konsumen datang ke dealer untuk melakukan negosiasi mengenai kendaraan yang akan di beli. Negosiasi ini meliputi harga, jenis kendaraan beserta seri dan type kendaraan, untuk masalah garansi, suku cadang dan service lain-lain. Negosiasi berlanjut dengan menyerahkan uang muka (down payment)

b. Dealer menawarkan barang yang di jual secara tunai atau kredit, menerima sejumlah uang muka (down payment) dan mengajukan aplikasi permohonan pembiayaan kepada perusahaan leasing.

c. Bagian marketing, menerima aplikasi konsumen dan menginput data aplikasi yang tertera untuk dikirim ke pihak BFI Finance.

d. Bagian surveyor, menerima aplikasi dari marketing dan dealer dan memproses lebih lanjut dengan melakukan pengamatan fakta lapangan ke calon nasabah dan melakukan analisis kredit untuk menilai kelayakan pembiayaan.

e. PT. BFI Finance memberikan pencairan dana pembiayaan kepada dealer sebagai pelunasan transaksi jual beli kendaraan.

f. Dealer menyerahkan barang kepada nasabah dan sebagai jaminan fasilitas pembiayaan yang diberikan, maka PT. BFI Finance menerima jaminan dari nasabah berupa bukti kepemilikan kendaraan bermotor (BPKB) dari kendaraan yang telah dibiayai dan jaminan pokok secara fidusia dengan kepemilikan akan berada pada perusahaan sampai angsuran pembayaran telah disampaikan lunas.

g. Nasabah memiliki kewajiban membayar angsuran secara berkala dalam jangka waktu tertentu sesuai kesepakatan.

Dalam pelaksanaan kegiatan usahanya PT. BFI Finance Indonesia menetapkan prosedur aplikasi pembiayaan seperti berikut ini :

1. Prosedur Permohonan Nasabah

Permohonan pembiayaan leasing diajukan pada perusahaan dengan melalui bagian pemasaran atau marketing dan juga costumer service dengan cara :

a. Permohonan dari calon nasabah yang diajukan melalui jaringan usaha atau dealer yang sudah bekerja sama dengan perusahaan. Syarat dan ketentuannya adalah :

1. Nasabah perorangan

a. Formulir aplikasi pinjaman

b. Fotokopi KTP pelanggan dan pasangan

c. Fotokopi Kartu Keluarga

d. Fotokopi Akta Nikah (jika sudah berkeluarga)

e. Fotokopi NPWP

f. Fotokopi PBB 2 tahun terakhir / rekening listrik 6 bulan terakhir

g. Fotokopi rekening tabungan / rekening koran 3 bulan terakhir

h. Asli slip gaji 3 bulan terakhir / SPPT terakhir

2. Perusahaan

a. Formulir aplikasi pinjaman

b. Fotokopi NPWP
Implementation of

Lease Accounting in Indonesia 
Implementation of

Lease Accounting

in Indonesia

\section{4}

c. Fotokopi PBB 2 tahun terakhir / rekening listrik 6 bulan terakhir

d. Fotokopi rekening tabungan / rekening koran 3 bulan trakhir

e. Fotokopi izin usaha (SIUP / TDP) / SPPT terakhir

f. Fotokopi Akta Pendirian Perusahaan dan perubahannya

g. Fotokopi Akta Pengesahan Kementerian Hukum dan HAM

h. Fotokopi identitas komisaris dan direksi

b. Dealer melanjutkan aplikasi ke PT. BFI Finance Indonesia melalui petugas pemasaran atau marketing di dealer/ jaringan usaha perusahaan dan diterima oleh credit marketing head yang kemudian akan dilakukan proses initial data entry untuk melihat apakah konsumen masuk dalam daftar hitam (black list). Lalu jika lolos maka akan dilakukan servei pengamatan fakta lapangan.

2. Prosedur Penilaian Kelayakan Calon Nasabah

Untuk menilai kepercayaan calon nasabah, maka dilakukan lah penilaian calon nasabah oleh bagian survei lapangan dengan prosedur sebagai berikut.

a. Survei dari PT BFI Finance Indonesia melakukan pengamatan fakta lapangan meneliti ke lokasi rumah nasabah untuk menilai kelayakan nasabah untuk melakukan pembiayaan. Dan menilai apakah nasabah tersebut layak untuk diberikan pembiayaan.

3. Prosedur Persetujuan

a. Berdasarkan hasil survei sebagai tim analisis fakta lapangan dan berdasarkan hasil laporan data yang didapat oleh si survei berisi kesimpulan pertimbangan apakah nasabah tersebut layak untuk dibiayai atau tidak.

b. Analisis yang dibuat merupakan sebuah kesimpulan yang baik positif ataupun negatif yang berdasarkan fakta lapangan . dan jika layak makan data tersebut akan dibawa kembali ke komite kredit yang dimana bertujuan untuk analisis permohonan pembiayaan untuk memperoleh keyakinan apakah nasabah mempunyai kemauan dan kemampuan untuk memenuhi pembayaran kepada perusahaan secara baik sesuai kesepakatan.

c. Komite kredit akan menilai, menganalisis dan memutuskan kesepakatan disetuji atau ditolak atas pengajuan kredit tersebut. Dan komite kredit akan memutuskan apakah kredit yang diajukan diterima atau ditolak. Jika diterima maka proses pengajuan akan dilanjutkan dengan pencairan dana.

\section{Perlakuan Akuntansi oleh Lessor \\ 1. Pencatatan Transaksi Sewa Guna Usaha}

Penentuan apakah suatu perjanjian merupakan perjanjian sewa itu didasarkan pada subtansi perjanjian pada tanggal awal sewa dan apakah perjanjian tergantung pada penggunaan suatu aset dan perjanjian tersebut memberikan suatu hak untuk menggunakan aset tersebut. Kembali lagi pada dasarnya yaitu jika sewa tersebut disebut sebagai sewa pembiayaan jika sewa tersebut mengalihkan secara subtansial seluruh resiko dan manfaat yang terkait dengan kepemilikan aset. Tetapi jika suatu sewa diklasifikasikan sebagai sewa operasi jika sewa tidak mengalihkan secara subtansial seluruh resiko dan manfaat yang terkait dengan kepimilikan aset. Dalam PSAK 30 ada beberapa hal yang harus diungkap oleh lessor dalam menyajikan laporan keuangan terkait sewa pembiayaan yaitu mengenai pengakuan awal, pengukuran setelah pengakuan, serta pengungkapan dan pelaporan sewa guna usaha serta perlakuan akuntansi sewa pada laporan keuangan yang akan penulis analisis bagaimana penyajian laporan keuangan akuntansi sewa pada PT. BFI Finance Indonesia Tbk.

Jenis sewa pada PT. BFI Finance adalah sewa pembiayaan (financial lease) yang dimana pada akhir masa sewa pihak lessee berhak memiliki aset yang disewa guna usahakan dan sewa tersebut mengalihkan secara subtansial seluruh risiko dan manfaat yang terkait dengan kepemilikan aset. Berikut adalah ilustrasi transaksi pencatatan sewa dalam laporan keuanga: Nasabah menginginkan motor bekas untuk keperluan bisnisnya dan konsumen memilih dealer motor dengan salah satu unit yang ingin di beli seharga 
Rp. 13.000.000,- serta mengambil tenor 12 bulan/ 1 tahun. Misal DP ditetapkan Rp. 3.000.000,- dan biaya admin adalah Rp. 600.000,- asuransi Rp. 500.000,-

\section{OTR}

DP

Pokok utang

angsuran

jangka waktu

DP

Angsuran pertama

Asuransi

Admin

Total bunga

Total hutang

Cicilan perbulan
: Rp. 13.000.000,-

: Rp. 3.000.000,-

: RP. 11.100.000,-

: RP. 1.105.000,-

: 12 bulan

: RP. 3.000,000,-

: RP. 1.105.00,-

: RP. 500.000,-

: RP. 600.000,-

: (pokok hutang $\mathrm{x}$ presentase bunga perbulan $\mathrm{x}$ tenor 12 bulan )

: $11.100 .000 \times 1.62 \%$ x $12=$ Rp. 2.157 .840 ,-

: Rp. 13.257.840,-

: $13.257 .840,-/ 12=1.104 .820$
Implementation of

Lease Accounting in Indonesia

Tabel 1 : Tabel Skema Angsuran

\begin{tabular}{|c|c|c|c|c|c|c|c|c|}
\hline \multirow{2}{*}{$\begin{array}{c}\text { periode } \\
1 \\
\end{array}$} & \multicolumn{2}{|c|}{ installment } & \multicolumn{2}{|c|}{ interest revenue } & \multicolumn{2}{|c|}{ principle paid } & \multicolumn{2}{|c|}{ account recevaible } \\
\hline & & & & & & & IDR & $13,257,840$ \\
\hline 1 & IDR & $1,104,820$ & & & IDR & $1,104,820$ & IDR & $12,153,020$ \\
\hline 2 & IDR & $1,104,820$ & IDR & 196,879 & IDR & 907,941 & IDR & $11,048,200$ \\
\hline 3 & IDR & $1,104,820$ & IDR & 178,981 & IDR & 925,839 & IDR & $9,943,380$ \\
\hline 4 & IDR & $1,104,820$ & IDR & 161,083 & IDR & 943,737 & IDR & $8,838,560$ \\
\hline 5 & IDR & $1,104,820$ & IDR & 143,185 & IDR & 961,635 & IDR & $7,733,740$ \\
\hline 6 & IDR & $1,104,820$ & IDR & 125,287 & IDR & 979,533 & IDR & $6,628,920$ \\
\hline 7 & IDR & $1,104,820$ & IDR & 107,389 & IDR & 997,431 & IDR & $5,524,100$ \\
\hline 8 & IDR & $1,104,820$ & IDR & 89,490 & IDR & $1,015,330$ & IDR & $4,419,280$ \\
\hline 9 & IDR & $1,104,820$ & IDR & 71,592 & IDR & $1,033,228$ & IDR & $3,314,460$ \\
\hline 10 & IDR & $1,104,820$ & IDR & 53,694 & IDR & $1,051,126$ & IDR & $2,209,640$ \\
\hline 11 & IDR & $1,104,820$ & IDR & 35,796 & IDR & $1,069,024$ & IDR & $1,104,820$ \\
\hline 12 & IDR & $1,104,820$ & IDR & 17,898 & IDR & $1,086,922$ & IDR & - \\
\hline
\end{tabular}

Jurnal pembelian aset sewa pada dealer

Aset sewa guna usaha Rp. 13.000.000,-

$$
\text { Kas Rp. 13.000.000,- }
$$

PT. BFI finance tidak menginvestasikan dana tunai kepada dealer, tetapi perusahaan akan mengeluarkan dana pembiayaan pada saat transaksi terjadi.

Jurnal saat transaksi mencatat lease:

Piutang sewa pembiayaan $\quad$ Rp. 13.257.840,-
Aset sewa guna usaha
Rp. 10.000.000,-
Pendapatan bunga diterima dimuka
Titipan premi asuransi
Rp. 2.757.840,-
Pendapatan administrasi ditangguhkan
Rp. 500.000,-

PT. BFI finance mengakui "aset sewa berupa piutang sewa pembiayaan sebesar jumlah yang sama dengan investasi sewa neto".

Jurnal untuk mencatat awal sewa perjanjian lease pada pembayaran pertama:

Kas

Rp. 1.104.820,-

Piutang sewa pembiayaan Rp. 1.104.820,-

Jurnal saat pembayaran angsuran ke 2:

Kas

Rp. 1.104.820,-

Pendapatan sewa pembiayaan Rp. 196.879,-

Piutang sewa pembiayaan

Rp. 907.941,-

Pengakuan penghasilan sewa pembiayaan didasarkan pada suatu pola yang mencerminkan suatu tingkat pengembalian periodik yang konstan atas investasi neto. 
Implementation of

Lease Accounting in Indonesia

$\underline{116}$

\section{Penyajian transaksi sewa guna usaha}

Dalam melakukan kegiatan operasi perusahaan transaksi sewa guna usaha yang dilakukan oleh perusahaan PT. BFI Finance Indonesia sebagai suatu perusahaan yang bergerak dibidang pembiayaan, PT. BFI Finance Indonesia tidak memiliki barang untuk diperjual belikan atau pun disewakan kepada konsumen melaikan langsung mengeluarkan dana kepada suplier,dealer atau langsung kepada konsumen pada saat terjadi suatu transaksi sewa. PT. BFI Finance Indonesia melakukan pencatatan aset lease bukan sebagai aset tetap tapi sebagai piutang dan menghentikan pengakuan aset dalam laporan posisi keuangannya. Lain halnya dengan perusahaan yang melakukan metode sewa operasi, yang berati perusahaan tersebut memiliki barang yang dapat diperjual belikan maupun disewakan kepada konsumen dan harus mencatat aset dalam laporan posisi keuangan serta mengakui penyusutan setiap tahunnya. Pada PT. BFI Finance Indonesia menggunakan metode financial lease atau sewa pembiayaan yang dimana berati perusahaan mengakui aset berupa piutang dan piutang tersebut disajikan dalam laporan posisi keuangan sebesar jumlah yang sama dengan investasi bersih. Untuk lebih jelasnya penulis akan sajikan laporan posisi keuangan dan pendapatan sewa pembiayaan neto.

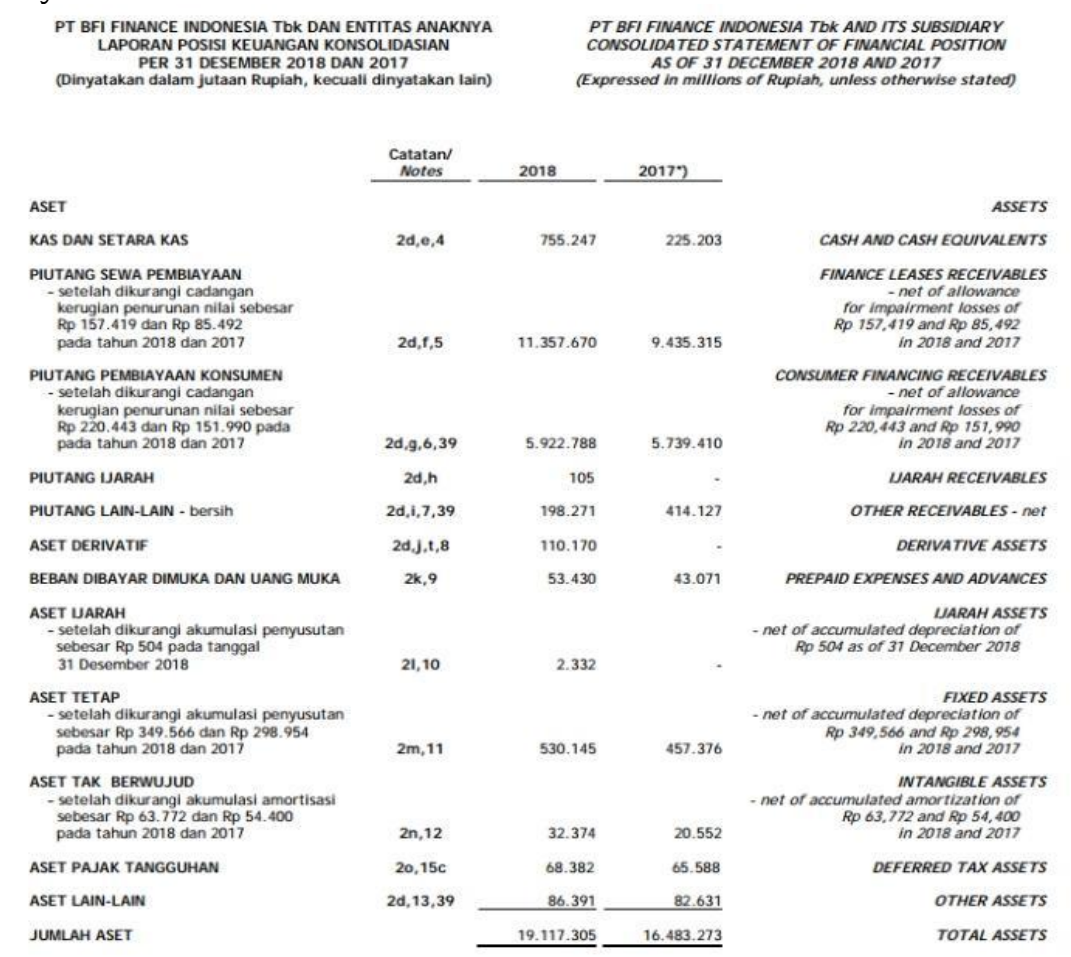

Sumber : Laporan Keuangan PT BFI Finance Indonesia Tbk Tahun 2018

Gambar 1 : Laporan Posisi Keuangan Konsolidasi BFIN

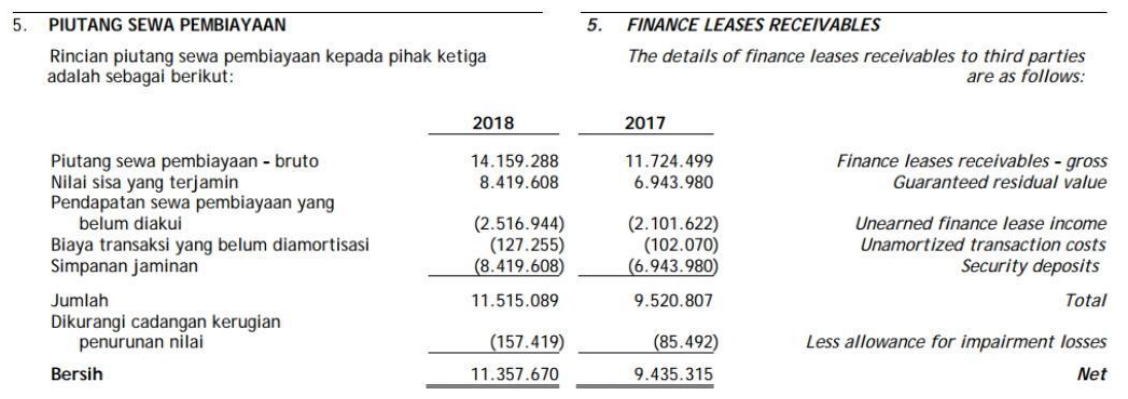

Sumber : Laporan Keuangan PT BFI Finance Indonesia Tbk Tahun 2018 Gambar 2 Pengungkapan Pendapatan Sewa Pembiayaan Neto BFIN 
Implementation of Lease Accounting in Indonesia

gambar 2 yang dimana investasi nilai bruto dan nilai kini piutang telah disajikan dalam akhir periode pelaporan. Dan untuk mengungkapkan investasi sewa bruto dan nilai kini piutang pembayaran sewa minimum pada tanggal pelaporan, untuk setiap periode berikut kurang dari satu tahun, lebih dari satu tahun dan lebih dari lima tahun akan disajikan sebagai berikut :

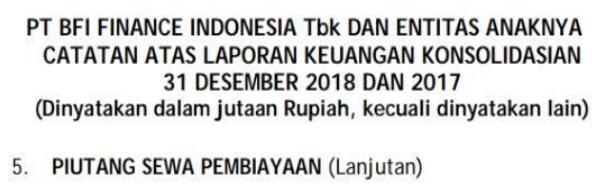

Angsuran piutang sewa pembiayaan - bruto yang akan diterima dari konsumen sesuai dengan tanggal jatuh temponya adalah sebagai berikut:

$<=1$ tahun
$1-2$ tahun
$>2$ tahun
Jumlah

\begin{tabular}{|c|c|}
\hline 2018 & 2017 \\
\hline 7.976 .514 & 6.699 .641 \\
\hline 4.441 .905 & 3.690 .044 \\
\hline 1.740 .869 & 1.334 .814 \\
\hline 14.159 .288 & 11.724 .499 \\
\hline
\end{tabular}

\begin{abstract}
PT BFI FINANCE INDONESIA TDK AND ITS SUBSIDIARY NOTES TO THE CONSOLIDATED FINANCIAL STATEMENTS 31 DECEMBER 2018 AND 2017
\end{abstract} (Expressed in millions of Rupiah, unless otherwise stated)

\section{FINANCE LEASES RECEIVABLES (Continued)}

The installments of finance leases receivables - gross, which will be collected from consumers in accordance with the due dates are as follows:

Sumber : Laporan Keuangan PT BFI Finance Indonesia Tbk Tahun 2018

Gambar 4. Pengungkapan angsuran piutang pembiayaan bruto BFIN Yang berati lessor mengungkapkan investasi sewa bruto dan nilai kini piutang pembayaran sewa minimum pada tanggal pelaporan disetiap periodenya sesuai dengan yang telah diperuntuhkan oleh PSAK 30.

1. Penghasilan pembiayaan tangguhan Pada laporan keuangan PT BFI Finance Indonesia per 31 desember 2018 telah menggungkapkan penghasilan pembiayaan tanguhan yang dimana itu adalah sebagai pendapaan sewa pembiayaan yang belum diakui yang disajikan dalam gambar 2 .

2. Nilai residu yang tidak dijamin yang diakru sebagai manfaat lessor. Laporan keuangan PT BFI Finance Indonesia tidak menggungkapkan nilai residu yang tidak dijamin karena nilai residu aset yang dimiliki PT BFI Finance Indonesia adalah nilai residu yang dijamin juga di perhitungkan dalam perhitungan investasi sewa bruto karena merupakan bagian dari pembiayaan sewa minimum.

3. Akumulasi penyisihan piutang tak tertagih atas pembayaran sewa minimum. Gambar 2 telah mengungkapkan akumulasi penyisihan piutang tak tertagih yang mengurangi investasi bersih dalam sewa pembiayaan. Untuk menemukan angka tersebut perusahaan mengungkapkan perhitungan yang akan disajikan dalam gambar berikut :

\begin{tabular}{|c|c|}
\hline $\begin{array}{l}\text { Saldo awal } \\
\text { Penambahan cadangan selama } \\
\quad \text { tahun berjalan - bersih } \\
\text { Penghapusan }\end{array}$ & $\begin{array}{r}12.472 \\
62.202 \\
(16.546) \\
\end{array}$ \\
\hline \multirow[t]{2}{*}{ Saldo akhir } & 58.128 \\
\hline & $\begin{array}{l}\text { Individual/ } \\
\text { Individual } \\
\end{array}$ \\
\hline $\begin{array}{l}\text { Saldo awal } \\
\text { Penambahan cadangan selama }\end{array}$ & - \\
\hline $\begin{array}{l}\text { Penambahan cadangan selama } \\
\text { tahun berjalan - bersih } \\
\text { Penghapusan }\end{array}$ & $\begin{array}{r}33.042 \\
(20.570) \\
\end{array}$ \\
\hline Saldo akhir & 12.472 \\
\hline
\end{tabular}

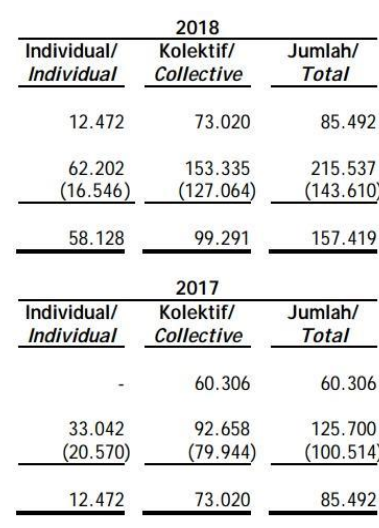

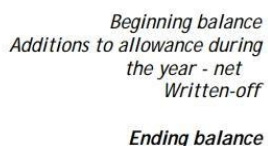
to finance leases recelvobance for impairment losses to finance leases receivables was $1.37 \%$ and $0.90 \%$ as of
31 December 2018 and 2017, respectively. Beginning balance the year - net Written-off Ending balance masing-masing pada tanggl 31 Desember 2018 dan 2017.

Sumber : Laporan Keuangan PT BFI Finance Indonesia Tbk Tahun 2018

Gambar 5 pengungkapan cadangan penurunan nilai piutang sewa pembiayaan BFIN 
4. Rental kontinjen yang diakui sebagai penghasilan dalam periode berjalan PT BFI Finance Indonesia tidak memiliki rental kontinjen sehingga tidak melakukan pengungkapan untuk rental kontinjen.

5. Penjelasan umum isi perjanjian sewa lessor yang material. PT BFI Finance Indonesia cukup mengungkapkan penjelasan secara umum isi perjanjian sewa lessor yang material dalam catatan atas laporan keuangan secara garis besarnya. Pada laporan keuangan PT BFI Finance Indonesia tertulis bahwa Sebagai jaminan atas piutang sewa pembiayaan yang diberikan, perusahaan menerima jaminan dari konsumen berupa buku kepemilikan kendaraan bermotor(BPKB) dan faktur atas kendaraan bermotor dan alat berat yang dibiayi oleh perusahaan. Pada saat perjanjian sewa pembiayaan dimulai, lessee memberikan simpanan jaminan. Simpanan jaminan ini akan digunakan sebagai pembayaran pada akhir masa sewa pembiayaan.

Penerapan akuntansi sewa guna usaha yang ditetapkan PT. BFI Finance Indonesia Tbk., secara garis besar telah sesuai dengan PSAK No.30 namun pada dasarnya semua perbandingan antara teori dan praktek tidaklah jauh berbeda. Opini audit dalam laporan keuangan BFIN menyatakan : Laporan keuangan konsolidasi terlampir menyajikan secara wajar, dalam semua hal yang material, posisi keuangan konsolidasi perusahaan dan entitas anaknya tanggal 31 desember 2018, serta kinerja keuangan serta arus kas konsoliasi yang berakhir untuk tahun yang berakhir pada tanggal tersebut, sesuai standar akuntansi keuangan di indonesia.

\section{PENUTUP}

Dalam pembahasan yang telah dibahas pada bab-bab sebelumnya maka dapat ditarik kesimpulan sebagai berikut :

1. Berdasarkan kriteria klasifikasi sewa yang ditetapkan dalam Pernyataan Standar Akuntansi (PSAK) 30 (Revisi 2011) tentang sewa, transaksi sewa yang dilakukan oleh PT. BFI Finance Indonesia Tbk diklasifikasikan sebagai sewa pembiayaan (financial lease) yang dimana pada akhir masa sewa pihak lessee berhak memiliki aset yang disewa guna usahakan dan sewa tersebut mengalihkan secara subtansial seluruh risiko dan manfaat yang terkait dengan kepemilikan aset.

2. Pada awal masa sewa pembiayaan dengan konsumen, perusahaan akan mengakui piutang sewa pembiayaan sebesar jumlah yang sama dengan investasi neto. Piutang tersebut akan berkurang pada saat perusahaan menerima pembayaran cicilan sewa. Penerimaan cicilan merupakan pembayaran pokok dan pendapatan sewa pembiayaan. Piutang sewa pembiayaan neto setelah di kurangi dengan penurunan nilai piutang disajikan dalam laporan posisi keuangan dan pendapatan pembiayaan disajikan dalam laporan laba rugi.

3. Berdasarkan analisis terhadap catatan atas laporan keuangan PT. BFI Finance Indonesia maka dapat diambil kesimpulan penerapan akuntansi sewa guna usaha di PT. BFI Finance Indonesia secara garis besar sudah sesuai dengan PSAK 30.

\section{DAFTAR PUSTAKA}

Bragg, Steven M. 2011 IFRS Made Easy, PT. Indeks. Jakarta

Buku standar akuntansi keuangan (sak) efektif per 1 januari 2017

Dewan Standar Akuntansi Keuangan PSAK No.30 Revisi 2011. IAI, Jakarta.

Hidayat, L., Muktiadji, N., \& Supriadi, Y. (2020, May). The Knowledge and Students' Interest to Investing in Investment Gallery. In 2nd International Seminar on Business, Economics, Social Science and Technology (ISBEST 2019)(pp. 142-145). Atlantis Press.

Ikatan Akuntansi Indonesia 2011, ED PSAK 30 (revisi 2011)

Ikatan Akuntansi Indonesia 2014, Pernyataan Standar Aakuntansi Keuangan. Jakarta
Implementation of

Lease Accounting in Indonesia 
Implementation of

Lease Accounting in Indonesia

120
Iriyadi, I., Setiawan, B., \& Sutarti, S. (2017). Pelatihan Analisis Data Penelitian (Primer Dan Sekunder) Bagi Mahasiswa Stie Kesatuan. Jurnal Pengabdian Masyarakat, 1(1).

Kasmir. 2016. Bank dan lembaga keuangan lainnya edisi revisi 2014. Rajawali pers. Jakarta

Kasmir. 2013. Analisis Laporan Keuangan, Jakarta: Raja Grafindo Persada.

Kieso,D.E., Weygant. J.J., dan Wrfeld, T.D 2011, Intermediet Accounting Volume 1 IFRS Edition. Wiley. United States of America.

Kusuma, R. D. (2020). Pelatihan Optimasi Media Sosial Untuk Peningkatan Omzet UMKM. Jurnal Abdimas, 4(3), 251-260.

Kusumayanti, D., \& Wibisono, S. (2020). Pendampingan Promosi Digital Bagi UMKM Kota Bogor. Jurnal Abdimas Dedikasi Kesatuan, 1(2), 171-180.

Laporan keuangan Keuangan Tahunan PT BFI Finance Indonesia Tbk 2018. Tersedia pada : http://www.idx.co.id

Martani, Dwi DKK. 2014. Akuntansi Keuangan Menengah Buku 1, Edisi 3. Erlangga , Jakarta

Meiky Sumual ,Dhullo Afandi (2016) ANALISIS PERLAKUAN AKUNTANSI LEASING DAN PELAPORANNYA PADA PT. ASTRA SEDAYA FINANCE DI MANADO

Muanas, M., Triandi, T., \& Rahmi, S. (2015). ANALISIS PERILAKU BIAYA DALAM HUBUNGANNYA DENGAN PERUBAHAN VOLUME KEGIATAN PERUSAHAAN. Jurnal Ilmiah Akuntansi Kesatuan, 3(1).

Muanas, M., \& Mulia, I. (2020). Pendampingan Penguasaan Akuntansi Dasar Bagi Pegawai BPR Mitra Daya Mandiri Bogor. Jurnal Abdimas Dedikasi Kesatuan, 1(1), 51-56.

Muanas, M., \& Mulia, I. (2020). Peningkatan Pemahaman Pembukuan Koperasi Melalui Pemograman Sederhana. Jurnal Abdimas Dedikasi Kesatuan, 1(2), 160-170.

Muktiadji, N., \& Gendalasari, G. G. (2016). Pengaruh Motivasi Belajar Dan Status Ekonomi Orang Tua Terhadap Minat Studi Lanjut Siswa/Siswi Sma Dan Smk Di Bogor Pada Bidang Ekonomi Dan Manajemen. Jurnal Ilmiah Manajemen Kesatuan, 4(3), 159-173.

Pamungkas, B., \& Iriyadi, I. (2012). Analisa Atas Pelaksanaan Audit Mutu Internal Untuk Mengevaluasi Efektifitas Penerapan Sistem Manajemen Mutu ISO 9001: 2000 Studi kasus pada PT. Murni Cahaya Pratama. Jurnal Ilmiah Kesatuan (JIK), 9(2).

Pamungkas, B. (2005). Peranan Internal Audit dalam Meningkatkan Pengendalian Intern Piutang: Studi Kasus pada PT. Vaksindo Satwa Nusantara. Jurnal Ilmiah Ranggagading (JIR), 5(1), 14-21.

Pradana, E. A. A. (2020). PKm-Pendampingan Tehnik Pembuatan Konten Promosi Digital Bagi UMKM Kota Bogor. Jurnal Abdimas, 4(1), 81-90.

Ria cristine (2013) PENERAPAN PSAK NO. 30 TENTANG PERLAKUAN AKUNTANSI SEWA AKTIVA TETAP PADA PD. BANGUN BITUNG

Rini annissa (2018) EVALUASI PENERAPAN PSAK 30 (REVISI 2011) TENTANG SEWA DAN DAMPAKNYA TERHADAP LAPORAN KEUANGAN LESSOR Studi kasus pada PT. Batavia Prosperindo Finance, Tbk. Cabang Bogor

Susilawati, N., \& Supriadi, Y. (2017). Pengaruh Cash Ratio dan Siklus Konversi Kas Terhadap Profitabilitas Perusahaan. Jurnal Ilmiah Manajemen Kesatuan, 5(2), 115124.

Warren, C.S., et al.. 2014. Pengantar Akuntansi Adaptasi Indonesia. Salemba Empat. Jakarta. 